\title{
Declining hegemony and the sources of Trump's disengagement from multilateral trade governance: the interaction between domestic politics and the international political economy
}

\section{Arlo Poletti ${ }^{1}\left[\right.$ L Lorenzo Zambernardi $^{2}$}

Accepted: 17 July 2021 / Published online: 5 August 2021

(c) The Author(s) 2021

\begin{abstract}
As a result of the economic and political rise of China and Trump's decision to undermine the liberal international order, theories of hegemony have regained center stage in both policy-oriented and scholarly debates. Yet, a careful analysis of the evolution of the US foreign policy strategy in the realm of international trade politics reveals that traditional theories of hegemonic decline are ill-equipped to account for both the timing and the content of the Trump administration's behavior in this issue area. This paper argues in favor of integrating structural theories of hegemonic transition/stability with an analysis of the domestic sources of trade policy preferences. To do so, we draw on the International Political Economy literature highlighting how the domestic political process triggered by the dynamics of international economic competition combined with structural forces in shaping the timing and content of the Trump administration's disengagement from the existing multilateral trade governance structures.
\end{abstract}

Keywords United States · Hegemony · Governance $\cdot$ Trade $\cdot$ International Relations

Arlo Poletti

arlo.poletti@unitn.it

Lorenzo Zambernardi

lorenzo.zambernardi3@unibo.it

1 Department of Sociology and Social Research, University of Trento, Via Verdi 26, 38121 Trento, Italy

2 Department of Political and Social Sciences, University of Bologna, Via Strada Maggiore 45, 40125 Bologna, Italy 


\section{Introduction}

As a result of the economic and political rise of the People's Republic of China and Trump's decision to undermine the foundations of the liberal international order, theories of hegemonic stability have regained center stage in both policy-oriented and scholarly debates. More or less explicitly, academics, policymakers, and pundits alike increasingly rely on the conceptual and theoretical toolkit of this important strand of research when discussing the evolving contemporary international system (e.g., Cooley and Nexon 2020; Foot 2020; Mastanduno 2019; Owen 2020),

Two observations, especially, have contributed to revitalize this research program. First, the institutional pillars of the international liberal order seem to be experiencing an irreversible decline, which seems to have its root cause in the US disengagement from multilateralism. Although the term "disengagement" has been employed to describe a variety of different actions ranging from total withdrawal from international accords to a gradual stop by great powers in their military presence and intervention abroad, here by this concept we refer to all policy choices designed to weaken a state's commitment to upholding existing or potential rule-based international governance mechanisms that support cooperation or coordination processes at the international level.

Second, the international system is experiencing a major change in the distribution of power as a result of the rapid growth of China. While there is no uniformity of views as to whether China's rise suffices to make it a superpower akin to the USA, particularly with regard to its technological and military capacity, there is unanimous consensus that its phenomenal economic growth is of systemic significance. More specifically, the pace and extent with which China has increased its economic, military and political weight over the last two decades calls into question how power is distributed within the international system as a whole, ultimately implying a relative decline of the US position.

The research agenda on hegemonic stability gained new popularity because it helped to make sense of the connections existing between these two broad developments in a simple, coherent, and seemingly plausible way. At the highest level of abstraction, different variants of hegemony theories share the view that the concentration of various kinds of resources in the hands of one state (i.e., hegemonic power) leads to the creation and maintenance of a stable international political and economic order (i.e., a hegemonic order). By extension, they also postulate that a shift in the relative distribution of these resources triggering the hegemonic decline and the concomitant rise of one or more hegemonic challengers should bring about international instability and disorder. Thus, in light of the relative decline of US power in the face of China's growth, at first glance theories of hegemony offer a plausible macro-level explanation of the observable deterioration of the American liberal-led order.

But how far can such a macro-level explanation account for observed patterns of US disengagement from the multilateral order of its own creation? In this paper, we focus on the evolution of the Trump administration's strategy of disengagement from multilateral trade governance and highlight two major limitations of 
explanations focusing exclusively on the structurally derived preferences of the USA as a declining hegemonic power. First, they have little to say about its timing. In particular, what explains the sudden shift from the Obama to the Trump administrations toward disengagement from the WTO? The Obama administration had already begun a strategic recalibration of US foreign policy to address the Chinese challenge with the so-called Pivot to Asia, but it always considered such initiatives as complementary to an open trading system still firmly embedded in the WTO. The Trump administration's frontal attack on the WTO marked a qualitative shift in terms of both the speed and nature of this strategic disengagement from multilateralism, which hegemonic stability theory is ill-equipped to explain.

Second and more importantly, the Trump administration's decision to disengage from multilateralism in the context of some regional trade governance mechanisms openly contradicts the behavioral expectations one could plausibly derive from theories of hegemony. Relative decline would suggest a greater willingness on the part of hegemons to strengthen their ties with allies so as to increase their ability to contain the rise of challengers. Yet, on his very first day of office as President of the USA, Trump signed an executive order to withdraw from the Trans-Pacific Partnership, a trade deal explicitly designed by the Obama administration to strengthen ties with US allies and create an effective instrument to contain China's economic rise. In other words, it is not at all obvious why US hegemonic decline should trigger withdrawal from what John Mearsheimer (2019) has termed the "bounded Western order."

In our view, theories of hegemony have limited explanatory power when it comes to making sense of the Trump administration's trade strategy of disengagement from multilateralism because they fail to specify how structural forces combine with micro-level political processes to determine particular policy outcomes (Lake 1993). In this article, we do not aim to develop a general and systematic theory of how structural forces combine with micro-level political processes to produce particular trajectories of declining hegemons' disengagement from multilateralism. More modestly, we draw on the International Political Economy literature to illustrate the potential of integrating "second image" (Singer 1961) and "second image reversed" (Gourevitch 1978) arguments to shed light on the trajectory of the Trump administration's disengagement from multilateral trade governance. In particular, our contribution makes a plausible case that the growing politicization of trade policy issues contributed to changing US domestic trade politics in ways that incentivized a swift disengagement from both international and bounded trade orders.

The politics of trade in the USA and elsewhere has traditionally been characterized by a political conflict between organized trade-related interests representing concentrated interests standing to lose (i.e., import-competing industries) or to win (i.e., export-oriented industries) from trade liberalization (De Bièvre and Dür 2005). However, this constellation of domestic political conflict changed due to growing skepticism about the merits of free-trade among key diffuse interests and large segments of US public opinion, making trade policy issues more salient and contested. This, in turn, created powerful incentives for President Trump to take a protectionist stance to muster support from an increasingly polarized and protectionist electorate and then, once elected, to deliver on these electoral promises. In short, as US trade 
policy-making became more politically charged domestically, strengthening ties with allies via trade deals became more politically difficult, ultimately generating incentives for a disengagement from both international and bounded trade orders.

The article proceeds as follows. The first section of the paper places US disengagement from multilateral trade governance in the context of hegemonic decline. The third part assesses the explanatory power of these theories in relation to Trump's trade policy, with particular reference to Mearsheimer's distinction between international and bounded orders. The final section examines the roots of Trump's trade policy, suggesting that it can largely be explained as an effect of the interplay between the structure of the international economy and US domestic politics.

\section{Hegemonic decline and US disengagement from multilateral trade governance}

Despite many important differences, all theories of hegemony advance two broad propositions. First, they suggest that the conditions for the existence of a liberal international economic order are political, ultimately boiling down to the presence of a single dominant player, i.e., a hegemonic power, which is both able and willing to use its power to create and maintain the norms and rules that allow such an order to exist (Levy 1991: 149). Second, they posit that hegemonic orders are bound to fall apart because the costs associated with maintaining the order, combined with technological diffusion in the periphery, trigger uneven growth among nations and, thus, inevitably make the hegemonic power lose its preeminent position (Gilpin 1981; Kohout 2003).

There is little doubt that theories of hegemony offer a compelling prima facie explanation for the evolution of the current international system, particularly after Donald Trump took office as President of the USA. For one thing, the correlation seems to be there: significant changes in the key independent variable produce, in the expected direction, noticeable changes in the dependent variable.

Although, since the end of the Cold War, according to various yardsticks of material power the USA has been literally a lonely superpower (Huntington 1999; Waltz 2009), over the last two decades it has undergone a significant decline in its relative power vis-à-vis China. Although the USA is still the world's largest economy with a nominal GDP of 21.4 trillion \$, China is quickly catching up, with a GDP of 14.1 trillion \$. Indeed, since China began to open up and reform its economy in the late 1970s, its GDP growth has averaged almost ten percent a year. In other words, while the USA's absolute economic weight keeps increasing, the gap in economic power between Washington and Beijing is shrinking.

Moreover, while the legitimating ideology that underpins US hegemonic power still enjoys considerable support across the world (Allan et al. 2018), there is clear evidence that support for China's global economic leadership is on the rise, particularly among developing countries and those economies that have experienced more financial troubles, more variable capital account policies, more volatile portfolio capital outflows, and more social unrest during IMF programs (Broz et al. 2020). Finally, few would contend that while China remains interested in working within the boundaries of the existing institutional order, Beijing is also simultaneously 
forging new economic and political ties through institutions like the Shanghai Cooperation Organization, the Belt and Road Initiative, the Asian Infrastructure Investment Bank (Goddard 2018), and the Regional Comprehensive Partnership Agreement.

In parallel, and consistently with the behavioral expectation deriving from theories of hegemony, the USA is disengaging from some multilateral institutions that constitute the building blocks of the liberal international order. Most notably, after Donald Trump won the presidential race, the USA engaged in a full-frontal attack on the institutional infrastructure underpinning the open international trading system. This is not to say that President Trump's strategy of disengagement from multilateralism was confined to trade. But this is the issue area where the US administration's attack on multilateralism was most visible, obstinate, and charged with far-reaching consequences. As soon as he took office, President Trump began a relentless campaign of obstruction aimed at paralyzing the WTO, by refusing to appoint new members of the WTO's appellate body and de facto stymying the whole institution. In the meantime, the US administration also formally withdrew from the Trans-Pacific Partnership (TPP), informally put a halt on Transatlantic Trade and Investment Partnership (TTIP) negotiations, signaling that its distrust for multilateralism was not confined to the WTO but extended to regional mechanisms of trade governance too. And on top of these initiatives, President Trump further shook the foundations of the open trading system by slapping steep tariffs on billions of dollars' worth of goods from the EU, Canada, Mexico and China on a unilateral basis.

What makes hegemonic stability theories particularly appealing as an analytical lens to account for Trump's strategy of disengagement from multilateral trade governance is that the mechanisms posited by theories of hegemony seem to have been indeed at play. Let us briefly consider the long-term dynamics underpinning the US strategy of disengagement from the WTO. The USA had been one of the major advocates of China's accession to the WTO, which eventually materialized in 2001. Underlying US strategy at the time was a positive-sum view about how to develop relations with China in the long term (Christensen 2006). Of course, China's accession to the WTO was expected to bring about commercial gains (i.e., greater access to the Chinese consumer market and a Chinese commitment to binding rules on Intellectual Property Rights). But President Clinton's strategy was motivated to a greater extent by the less tangible political goal of integrating China firmly within the USA-led international order, while hoping to trigger domestic processes of political reform.

Soon, however, it became clear that such optimism was ill-founded. Over the years, the WTO proved a formidable instrument that helped boost China's export-led economic growth, providing Chinese exporters with predictable and non-discriminatory access to nearly all foreign markets, while it did not similarly increase the USA's or other major trading powers' capacity to access the Chinese market (Iancovichina and Martin 2004). By way of illustration, in 2001, as it joined the WTO, China's GDP stood at 1.33 trillion USD, ranking 6th among the world's economies. In 2014, China's GDP topped 10 trillion USD, increasing by nearly 8 times, and ranking 2nd globally. Similarly, China's trade in goods in 2001 was valued at 0.51 trillion USD, ranking 6th in the world, while in 2014 it reached 4.3 trillion USD, 
growing over 8 times, and making it the world's largest trade power. Although it may appear ironic, it is no coincidence that today it is China, a country with an illiberal political regime, which is the champion of international economic liberalism, defending the open world economy from the state which created it in the post-WWII period.

The dynamics of negotiations and power relations within the WTO after China's accession may help explain this outcome. A key component of the US recipe to minimize the impact of China's entry into the WTO was the reform of global trade rules. Thus, concomitantly with China's accession, the USA and the European Union (EU) sponsored the launch of a new round of multilateral trade negotiations, the Doha Development Round, which was expected to expand the WTO's functional scope to a new set of regulatory issues such as services, investments, IPRs, and technical barriers to trade (Poletti 2012). Although the Uruguay Round had already kickstarted this process, global trade rules remained largely designed to facilitate trade in manufactured goods, making them particularly well-suited to accommodate the rise of China as the manufacturing power-house of the global economy. Thus, with the Doha Round the USA (and the EU) sought to rewrite the global trade rules in order to make them better suited to accommodate their own offensive interests (i.e., services, investments, and IPRs) in exchange for granting Chinese exporters access to their manufactured goods markets (De Bièvre and Poletti 2014).

As negotiations began, however, it became clear that reaching an agreement on these terms was far from a foregone conclusion. A coalition of emerging economies led by China made it clear that, contrary to the past, the USA and the EU alone would no longer be able to steer the course of WTO negotiations in line with their preferences, leading to an impasse that continued over time and ultimately prevented the Doha Round from delivering any substantive result (Narlikar 2010). In short, the failed attempt by the USA and the EU to redefine the terms of global trade rules in their own favor enabled China to continue operating within a multilateral trading system that perfectly suits its interests as the new leading global exporter of manufactured goods.

The official document stating the Trade Policy Agenda of newly elected President Trump (USTR 2017) offers perhaps the best possible piece of evidence in support of the claim that the causal mechanisms postulated by hegemonic stability theory were indeed at play in shaping US disengagement from the WTO. After arguing at length how China's accession to the WTO contributed to the worsening of US economic performance across a wide array of indicators, the document makes a direct link between China's gains deriving from the current international trade regime and the need for a new commercial policy: "while the current global trading system has been great for China, since the turn of the century it has not generated the same results for the United States. [...] it is time for a new trade policy that defends American sovereignty, enforces U.S. trade laws, uses American leverage to open markets abroad, and negotiates new trade agreements that are fairer and more effective both for the United States and for the world trading system.” (USTR 2017: 6-7). 


\section{Missing spots and inconsistencies}

While at first glance theories of hegemony do a good job in accounting for the US disengagement from multilateral trade governance, a number of factors suggest that their explanatory power should not be overstated. In particular, closer investigation of how the US trade strategy has changed in recent years suggests that the macrolevel explanation is limited in two important respects.

First, even if a plausible case can be made that relative hegemonic decline on the part of the USA was one of the main concerns motivating Washington to disengage from multilateral trade governance, theories of hegemony are ill-equipped to explain the exact timing of the key strategic shifts, particularly those enacted by President Trump. The case of the WTO is again very helpful here. As the previous section suggests, concerns about China's capacity to make disproportionate and asymmetrical gains from the multilateral trading system were a key to motivating the Trump administration's choice to systematically boycott the WTO and turn toward a market strategy of unilateralism in trade policy. Yet, this theoretical perspective has little to say about the factors that triggered the sudden strategic shift from the Obama to the Trump administration. Concern about China's rise and the USA's relative decline is by no means exclusive to the Trump administration. It dates back at least to the Bush administration, which had already started thinking about a "return to Asia"; and it fully matured during the first Obama administration (Barfield 2016). Thus, by the so-called Pivot to Asia (US Government 2011) the Obama administration upgraded the US role in the Asian Pacific region, raising that region's priority in US military planning, foreign policy and trade policy, precisely with a view to balancing China's rise and protecting the US position at the apex of the global hierarchy (Manyin et al. 2012). In other words, concerns about China's rise were crucial in shaping US strategy well before Trump took office. And yet, the Obama administration never questioned the American lead role within the multilateral trading system (US Government 2014: 4-9). Clearly, concern about relative hegemonic decline in the face of China's rise cannot, alone, explain the timing of the US disengagement from the WTO and the related shift toward unilateral protectionism. As Levy insightfully argued (1991), while theories of hegemony generally emphasize that disequilibrium creates the necessary conditions for particular sets of actions by the hegemon, they remain silent about the additional triggers that work in conjunction with those conditions to determine the timing of such behavior.

Second, and perhaps more importantly, the Trump administration's decision to disengage from some multilateral trade agreements stands in sharp contrast with how one could plausibly have expected the USA to behave on the basis of theories of hegemony. These theories broadly interpret the US trade policy shift as a means to mitigate the relative decline of the USA and prevent China from reaching the top of the global hierarchy. While the US disengagement from the WTO is broadly consistent with this interpretation, Washington's disengagement from multilateral trade 
arrangements with the existing and potential allies in a period of increasing competition and tensions with Beijing is not. In order to make this point clearer, let us recall Mearsheimer's (2019) distinction between international and bounded orders.

According to the neorealist scholar, orders are organized groups of international institutions that help govern the interaction among member states. They can be international, when they contain nearly every country in the system. They are bounded when they consist of a set of institutions that have limited membership. While international orders are virtually universal, bounded orders are usually regional in scope and dominated by a single great power (Mearsheimer 2019: 11-12). ${ }^{1}$ International orders help great powers to cooperate with each other. On the contrary, bounded orders help great powers to compete with opposing great powers. For within a bounded order cooperation is envisioned as an instrument to wage security competition with great powers that remain outside it.

Strictly speaking, the arguments developed so far are arguments about the US hegemonic decline and the international order. Accounting for the timing of US disengagement from the WTO may be beyond the scope of theories of hegemony, but the former is clearly consistent with the latter: the more the WTO furthers the dynamics that underpin the US relative decline vis-à-vis China, the higher the incentive for the USA to disengage from it. However, when it comes to bounded orders, the very logic of theories of hegemony makes it plausible to expect the opposite: relative decline can be expected to increase a hegemon's willingness to strengthen its ties with the members of the bounded orders they lead because it is instrumental to increasing their ability to contain the rise of a hegemonic challenger.

In the context of an assessment of US trade policy, this line of argument suggests the desirability of governance mechanisms designed simultaneously to help strengthen ties with US allies and contain China's economic rise. That is exactly what the Obama administration did in 2010 when it pushed for negotiations to wind up the Trans-Pacific Partnership (TPP). The TPP initiative was part of a broader US strategy aimed at containing China's challenge in general, and as an effective tool to reduce China's export-led growth in the Asia-Pacific region in particular (Poletti 2017).

To understand the logic underpinning this strategy, a brief incursion into the political economy of trade agreements is in order here. Because members of a trade agreement eliminate/reduce tariffs against each other, while continuing to levy tariffs against imports from third countries, they produce two effects: they create new trade between signatories, but they simultaneously decrease trade and investments between signatories and the outside world (Baccini and Dür 2015). Thus, comprehensive estimates of the TPP's welfare effects show that, while potentially yielding significant annual increases in US real incomes, exports, and outward and inward FDIs, the agreement would indeed simultaneously entail significant costs for China,

\footnotetext{
1 Mearsheimer argues that all states seek to maximize their power relative to one another with the ultimate aim of becoming the hegemon. He defines a hegemon as a "great power with so much actual military capability and so much potential power that it stands a good chance of dominating and controlling all other great powers in its region of the world" (Mearsheimer, 2001: 44-45).
} 
the most important Asian trading partner excluded from the agreement (Petri and Plummer 2016; Schott et al. 2013). ${ }^{2}$

The case of the TPP thus makes it clear that, far from being inconsistent with theories of hegemony, a strategy of multilateral engagement within bounded orders can be instrumental to effectively advancing the interests of a declining hegemon. As nicely put by Blackwill and Tellis (2015: 4) in the report Revising US Grand Strategy Toward China, "because the American effort to integrate China into the liberal international order has now generated new threats to U.S. primacy in Asiaand could eventually result in a consequential challenge to American power globally-Washington needs a new grand strategy toward China that centers on balancing the rise of Chinese power rather than continuing to assist its ascendancy." Sustaining US status in the face of China's rising power, according to the Report, would require, among other things, "creating new preferential trading arrangements among US friends and allies to increase their mutual gains through instruments that consciously exclude China" (Ibidem: 5).

Despite its potential to act as an effective instrument to contain China's economic rise, on the very first day of his office Trump signed an executive order to withdraw from the TPP, going exactly in the opposite direction from how one might have expected Washington to behave on the basis of hegemonic theory, showing that the USA was unwilling to provide even limited leadership within the Western bounded order.

\section{The domestic sources of hegemonic disengagement from multilateral trade governance}

The above discussion suggests that the theory of hegemonic stability, with its exclusive focus on the structurally derived preferences of a declining hegemon, does not suffice to account for the timing and, most importantly, the content of the Trump administration's strategy of disengagement from multilateral trade governance. In line with works highlighting the interplay of domestic and international factors in explaining foreign policy choices (Colgan and Keohane 2017; Musgrave 2019; Putnam, 1988; Milner 1997), we believe that in order to develop a convincing account of the determinants of Trump's disengagement from multilateral trade governance it is necessary to combine system-level explanations with analyses highlighting domestic variables.

It is beyond the scope of this article to tackle the broader challenge of developing a general systematic theory of how structural forces combine with micro-level political processes to produce a hegemon's disengagement from hegemonic orders. More modestly, we rely on two established strands of political-economy literature to illustrate the plausibility of the argument that domestic political dynamics,

\footnotetext{
22013 estimates suggested the TPP would cause an annual decrease in China's real incomes by 46.8 billion ( 0.3 percent below the baseline), largely due to an annual export decrease by 57.4 billion (1.2 percent below the baseline) (Schott et al. 2013).
} 
engendered by international economic competition, combined with strategic trade considerations in shaping Trump's trade policy strategy. In particular, we tentatively put forward and briefly illustrate the argument that the way in which the Trump administration reacted to the structural incentives brought about by the US relative decline can be plausibly traced back to the growing domestic politicization of trade policy issues. In turn, such a process produced significant additional domestic political constraints on the USA engaging in reciprocal trade-opening concessions and, as a consequence, incentivized a swift disengagement from the WTO and the TPP.

The following empirical analysis must be considered as a "plausibility probe" with the goal of showing the empirical relevance of our argument (Eckstein 1975). Plausibility probes play a crucial role in the process of theory development, particularly when used as preliminary studies on relatively untested arguments such as the ones presented in this article. They serve as an intermediate stage before moving toward systematic hypothesis construction and time-consuming empirical tests (Eckstein 1975: 108-13; George and Bennett 2005: 75; Levy 2008: 7).

\section{Traditional trade politics}

Traditional approaches to studying the politics of trade conceive of countries' trade policy choices as a function of the preferences, patterns of political mobilization, and influence of organized trade-related domestic interests. Although views diverge as to whether conflicts in the making of trade policy run along factoral, sectoral or firm-level lines (Hiscox 2001; Kim 2017), these works concur in seeing trade policy choices as the result of political conflict between organized lobby groups representing the winners and the losers of trade liberalization. In short, these approaches usually focus on the political struggle between organized trade-related interests standing to lose (i.e., import-competing industries) or to win (i.e., export-oriented industries) from trade liberalization, suggesting that governments should consistently strive to improve foreign market access for its exporters while protecting domestic sectors threatened by foreign competition (De Bièvre and Dür 2005; Grossman and Helpman 1994; Milner and Rosendorff 1997; Rosendorff and Smith 2018).

At first glance, the evidence would seem to run counter to the argument that the roots of Trump's disengagement from the TPP lay in the successful lobbying efforts of the domestic groups opposing it since some major American business groups generally supported the negotiations. These included the Business Roundtable (2016), the American Chamber of Commerce (see US Chamber of Commerce 2016), the American Farm Bureau Federation (2015), the National Small Business Association (2015), and the National Retail Federation (2015). However, closer inspection reveals that the domestic lobbying landscape over TPP was far from homogeneous. For instance, while the National Association of Manufacturers did express its support for the TPP (National Association of Manufactures 2016), it was internally divided, with many members expressing deep skepticism toward the agreement. ${ }^{3}$ Other organizations representing the manufacturing sector, such as the Alliance for

3 https://chiefexecutive.net/manufacturers-mixed-opinions-leaving-tpp/.

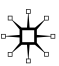


American Manufacturing, explicitly expressed full support for Trump's decision and called for further steps in a similar direction. But the deal was opposed by many other powerful interest groups, including automakers fearing competition by Japanese producers, pharmaceutical companies expressing concern about IPRs as provided by the agreement, and the tobacco industry. Finally, the deal was also vocally opposed by organizations representing more diffuse interests, such as the American Federation of Labor and Congress of Industrial Organizations (AFL-CIO 2016) and various consumer and environmental justice groups (Citizens Trade Campaign 2016).

This brief overview underscores that the TPP negotiations were characterized by traditional conflict lines between different trade-related organized interests. On the one hand, organizations representing exporting interests and importers of intermediates generally welcomed the agreement, while groups representing the interests of the likely losers from the agreement (e.g., trade unions, organizations representing comparatively disadvantaged manufacturers and NGOs) opposed it. The presence of intense political conflicts between organized societal groups representing concentrated trade-related interests is a typical feature of any major trade negotiation and seems therefore unlikely to be, alone, a major cause of the sudden trade policy strategy shift enacted by the Trump administration. Indeed, other domestic factors combined with these dynamics to produce the disengagement from multilateral trade governance pursued by the Trump administration. As we suggest in the next section, such a major trade policy shift can be better understood if one considers these patterns of political conflict by traditional trade-related interests in combination with the effects generated by the growing politicization of trade policy in the USA.

\section{The politicization of US trade policy}

Much research has recently focused on the politicization of trade policy across major advanced economies in the last decade (see De Bièvre and Poletti 2020 and Walter 2021 for an overview). The concept of politicization draws attention on the fact that trade policy is increasingly characterized by patterns of political conflict that can no longer be accurately captured by traditional models of trade politics. Politicization refers to a three-dimensional process involving increasing salience, polarization of opinion, and the expansion of actors and audiences involved in policy issues (see also De Bruycker, 2017; De Wilde et al. 2016). Trade policy issues can therefore be considered politicized when the general public is aware of and cares about trade policy decisions (i.e., saliency), when they contribute to polarizing political debates and opinions (i.e., polarization), and when they trigger the political mobilization of numerous political actors beyond the relatively closed circle of trade policy officials and groups representing trade-related interests, such as NGOs and various kinds of citizen organizations (i.e., actor expansion).

A wide array of studies suggests that the politics of trade in the USA has indeed become increasingly politicized. For instance, recent works building on the long tradition of studies focusing on the links connecting trade openness to individuals' political attitudes and voting behavior have much to say about how globalization might have fed into the domestic politics of the USA, making it more politicized 
and, ultimately, contributing to nurturing Trump's trade policy shift toward disengagement. In particular, China's accession to the WTO in 2001 triggered a huge rise of exports in the USA, which caused higher unemployment, lower labor force participation, and a wage reduction in local labor markets containing import-competing manufacturing industries (Autor et al. 2013). The adverse consequences of increased import-competition from China, which have been particularly severe in the Midwest and parts of the South, where American manufacturing is concentrated, had a clear political impact on American politics. First, as suggested by Di Tella and Rodrik (2020) and in line with previous research showing that support for protectionism is generally higher among individuals employed in sectors and occupations that are more highly exposed to import-competition (Hays et al. 2005; Mayda and Rodrik 2005; Mansfield and Mutz 2009; Margalit 2012; Scheve and Slaughter, 2004), international competition contributed to increasing popular support for protectionism in the USA. Second, in the last two decades the electoral districts most exposed to rising trade with China have consistently experienced an ideological re-alignment favoring more extreme and protectionist politicians across both congressional and presidential elections in the USA (Autor et al. 2016a; Feigenbaum and Hall 2015). Moreover, such increased polarization generated incentives for endogenous policy re-alignments which reinforced protectionist stances within US parties (Musgrave 2019). Finally, these processes ended up crucially shaping the results of the 2016 Presidential election. For instance, examining crucial swing states, Jensen et al. (2017) find that the negative effect of comparatively disadvantaged manufacturing employment on incumbent vote shares was approximately three times as large as in non-swing states, which led to a powerful Electoral College incentive to protect this sector and oppose trade agreements, crucially contributing to Trump's electoral success (Blendon et al. 2017). Overall, these studies underscore the plausibility of the argument that the political climate on trade policy issues preceding the election of Trump was highly politicized.

\section{The domestic roots of disengagement}

The above brief overview highlights two important points. Firstly, it suggests the plausibility of the argument that domestic societal pressures contributed to shaping how the Trump administration responded to the structural incentives brought about by China's relative rise when it came to defining US trade policy strategy. On the one hand, such a "domestic" perspective highlights the strength of the nexus between the timing of the US disengagement from the international trade order embedded in the WTO and President Trump's incentives to deliver on the electoral promises that proved so effective in mustering support from an increasingly polarized and protectionist electorate. On the other hand, it stresses that, in addition to being consistent with the protectionist profile of its electorate, Trump's decision to disengage from the Western bounded order embedded in the TPP was in line with demands voiced by a number of relevant domestic constituencies.

Taken together, these observations suggest that the particular trajectory of the Trump administration disengagement from multilateral trade governance was the result of the growing domestic politicization of trade policy issues in the USA. 
Traditional opposition to trade opening from organizations representing concentrated interests was reinforced by the vocal opposition of groups representing diffuse interests and by a skeptical public opinion. This political climate motivated Trump to take a protectionist stance so as to muster support from an ever-more polarized and protectionist electorate and then, as a consequence, to deliver on these electoral promises. Hence, both the timing and the content of disengagement from multilateralism seem to have had strong roots in the effects of international trade competition on American domestic politics. In this sense, Trump's unprecedented hostility toward the WTO and withdrawal from the TPP can be seen as the end result of a causal chain: (1) a huge rise in Chinese exports to the USA, (2) growing opposition toward free-trade within large segments of American society that combined with opposition to trade opening by traditional organized concentrated interests, (3) creation of strategic incentives for candidates, such as Trump, to take a tough protectionist stance to secure an electoral advantage, and (4) delivery of this political agenda through a radical departure from the status quo (i.e., the multilateral trade system).

These patterns underscore the importance of focusing on the domestic roots of the Trump administration's strategy of disengagement from multilateral trade governance. Not coincidentally, a flurry of political-economy research has investigated the links that connect globalization to the rise of populism across western democracies (e.g., Eichengreen 2018; Rodrik 2018; Frieden 2019; Walter 2021). The overarching contention of such scholarly literature is that populism, with its marked rejection of global economic openness and multilateral cooperation, has much to do with a number of processes closely associated with how globalization has unfolded throughout the last three decades. Growing trade and investment links across the globe have certainly contributed to lifting hundreds of millions of people out of poverty, especially in East Asia and India (Deaton 2013). However, these phenomena have also generated major economic problems inside developed countries. In the period preceding the end of the Cold War, developed countries had managed to maintain popular support for globalization through redistributive mechanisms (e.g., the welfare state), which effectively cushioned individuals from the negative distributional consequences of global economic integration (Cameron 1978; Katzenstein 1985; Rodrik 1998; Ruggie 1982). Yet, while the growing exposure of domestic economies to the vagaries of an increasingly integrated global economy boosted the demand for social protection in the face of increasing dislocation, occupational mobility, off-shorability, and income inequality, it concomitantly generated severe constraints on governments' ability to provide protection for the losers of globalization. In short, this branch of scholarship sees the rise of populism as the result of a popular reaction triggered by material dislocations generated by the decline of the "embedded liberalism compromise" (Franzese 2019; Kriesi 2014).

While this literature is chiefly concerned with the rise of populist movements and parties, it can be usefully employed to illuminate the bottom-up dynamics that work in conjunction with structural forces to determine the speed and content of the US disengagement from multilateralism. A declining hegemon such as the USA faced, and still faces, structural incentives pushing in the direction of rethinking its engagement within the multilateral trade governance it created. The specific ways in which it chooses to do so, however, largely depend on the domestic political constraints set 
by the demands of various societal actors. Disengagement from both the international and bounded trade orders became an attractive, rewarding political option for the Trump administration in a context that was marked by a high degree of politicization of trade policy issues.

\section{Conclusion}

The article suggests that making sense of the timing and content of the Trump administration's disengagement from the existing multilateral trade governance requires specifying how international structural forces interact with domestic political processes. In fact, this analysis does not aim to emphasize the primacy of domestic politics, but rather the need to uncover how structural variables combine with micro-level political processes to produce particular trade policy outcomes.

What implications can we draw from this study for the future commercial policy of the new Biden administration? In our view, the rise of populist sentiment in American society played a key role in determining Trump's trade policy. Indeed, typical features of a populist leadership are its rhetoric against concentrated interests and the attempt to restore unity in the name of the people, represented by individuals and small, diffuse interests. Moreover, Trump's policy seems consistent with the idea of populism as a "thin-centered ideology" (Mudde 2004), based on the notion of a mendacious political ruling class that furthers the interests of the (globalized) economic elite against the commonweal of the people. Whether the Biden administration will bring about continuity with or change from Trump's policy of disengagement from multilateral trade governance ultimately depends on the level of politicization of trade policy issues. In particular, it will depend on whether such politicization will prove to be exogenous or endogenous to the Trump presidency, meaning whether politicization was solely an effect of the current structure of the international economy or had other deeper domestic roots. In the former case, we should expect President Biden to persist in dismantling the liberal global economic order. In the latter, two apparently diverging policies are likely to be implemented. On the one hand, President Biden will probably act in a more cooperative and less competitive way vis-à-vis America's traditional allies and partners in the Western bounded order. On the other, in order to contain its hegemonic rival and protect the relative US position in the global hierarchy, his administration is likely to continue to implement an aggressive trade policy toward China. President Biden's present confrontational attitude toward Beijing and his strengthening of ties with traditional allies in Europe and Asia suggest that the USA is opting for this latter policy. Indeed, while stating that "Diplomacy is back at the center of our foreign policy," Biden has also been unequivocal in establishing domestic concerns as a priority of his administration (e.g., Made in America). Multilateralism will be resurrected but with a view to the fate of labor at home. 
Funding Open access funding provided by Università degli Studi di Trento within the CRUI-CARE Agreement.

\section{Declarations}

Conflict of interest The authors declare that they have no conflict of interest.

Open Access This article is licensed under a Creative Commons Attribution 4.0 International License, which permits use, sharing, adaptation, distribution and reproduction in any medium or format, as long as you give appropriate credit to the original author(s) and the source, provide a link to the Creative Commons licence, and indicate if changes were made. The images or other third party material in this article are included in the article's Creative Commons licence, unless indicated otherwise in a credit line to the material. If material is not included in the article's Creative Commons licence and your intended use is not permitted by statutory regulation or exceeds the permitted use, you will need to obtain permission directly from the copyright holder. To view a copy of this licence, visit http://creativecommons.org/licen ses/by/4.0/.

\section{References}

AFL-CIO. 2016. AFL-CIO's Final "Written Submission" for the U.S International Trade Commission's Investigation on TPP Impacts, 13-15 January.

Allan, B.B., S. Vucetic, and T. Hopf. 2018. The distribution of identity and the future of international order: China's hegemonic prospects. International Organization 72 (4): 839-869.

American Farm Bureau Federation. 2015. Statement by Bob Stallman, President, American Farm Bureau Federation Regarding AFBF Support for TPP. 15 December, https://ustr.gov/sites/default/files/State ment\%20by\%20Bob\%20Stallman.pdf. Accessed 28 July 2021.

Autor, D.H., D. Dorn, and G.H. Hanson. 2013. The China syndrome: local labor market effects of import competition in the United States. American Economic Review 103 (6): 2121-2168.

Autor, D.H., Dorn, D. Hanson, G.H. and Majlesi, K. 2016. A note on the effect of rising trade exposure on the 2016 Presidential election. Working paper (November), https://economics.mit.edu/files/ 12418. Accessed 28 July 2021.

Baccini, L., and A. Dür. 2015. Investment discrimination and the proliferation of preferential trade agreements. Journal of Conflict Resolution 59 (4): 617-644.

Barfield, C. 2016. Trans-Pacific partnership and America's strategic role in Asia. In The Trans-Pacific Partnership and the Path to Free Trade in the Asia-Pacific, ed. P. Chow, 30-48. Cheltenham: Edward Elgar.

Blackwill, R. and Tellis, A. 2015. Revising US grand strategy toward China. Council Special Report 72. New York: Council on Foreign Relations, https://carnegieendowment.org/files/Tellis_Blackwill.pdf. Accessed 10 November 2020.

Blendon, R.J., S.C. Logan, and J.M. Benson. 2017. Public opinion and trump's Jobs and trade policies. Challenge 60 (3): 228-244.

Broz, J., Z. Zhang, and G. Wang. 2020. Explaining foreign support for China's Global Economic Leadership. International Organization 74 (3): 417-452.

Business Roundtable. 2016. America's business leaders support Trans-Pacific partnership, January 5; https://www.businessroundtable.org/archive/issues/international-engagement?page $=11 . \quad$ Accessed 17 October 2020.

Cameron, D.R. 1978. The expansion of the public economy: a comparative analysis. American Political Science Review 72 (4): 1243-1261.

Christensen, T.J. 2006. Fostering stability or creating a monster? The rise of China and U.S. policy toward East Asia. International Security 31 (1): 81-126.

Citizens trade campaign. 2016. Over 1.500 organizations urge opposition to the TPP, 7 January, https:// www.citizenstrade.org/ctc/blog/2016/01/07/1500-groups-urge-congress-to-oppose-the-tpp/. Accessed 2 October July 2020. 
Colgan, J.D., and R.O. Keohane. 2017. The liberal order is rigged: fix it now or watch it wither. Foreign Affairs 96 (3): 36-44.

Cooley, A., and D. Nexon. 2020. Exit from Hegemony: The Unraveling of the American Global Order. Oxford: Oxford University Press.

De Bièvre, D., and A. Dür. 2005. Constituency interests and delegation in European and American trade policy. Comparative Political Studies 38 (10): 1271-1296.

De Bièvre, D., and A. Poletti. 2014. The EU in trade policy: From regime shaper to status quo power. In EU Policies in a Global Perspective: Shaping or taking international regimes?, ed. G. Falkner and P. Müller, 20-37. London and New York: Routledge.

De Bièvre, D., and A. Poletti. 2020. Towards explaining varying degrees of politicization of EU trade agreement negotiations. Politics and Governance 8 (1): 243-253.

De Bruycker, I. 2017. Politicization and the public interest: when do the elites in Brussels address public interests in EU policy debates? European Union Politics 18 (4): 603-619.

De Wilde, P., A. Leupold, and H. Schmidtke. 2016. Introduction: the differentiated politicisation of European governance. West European Politics 39 (1): 3-22.

Deaton, A. 2013. The great escape: health, wealth, and the origins of inequality. Princeton and Oxford: Princeton University Press.

Eckstein, H. 1975. Case studies and theory in political science'. In F. Greenstein, and N. Polsby (eds.) Handbook of Political Science, vol. 7. Reading, MA: Addison-Wesley, pp. 79-138.

Eichengreen, B. 2018. The Populist Temptation: Economic Grievance and Political Reaction in the Modern Era. New York: Oxford University Press.

Feigenbaum, J.J., and A.B. Hall. 2015. How legislators respond to localized economic shocks: evidence from Chinese import competition. Journal of Politics 77 (4): 1012-1030.

Foot, R. 2020. China's rise and US hegemony: renegotiating hegemonic order in East Asia? International Politics 57 (1): 150-165.

Franzese, R.J. 2019. The comparative and International Political Economy of Anti-Globalization Populism, Oxford Research Encyclopedia of Politics, 26 April. https://doi.org/10.1093/acrefore/97801 90228637.013 .638

Frieden, J. 2019. The backlash against globalization and the future of the international economic order. In The Next Phase of Globalization: Capitalism and Inequality in the Twenty-First Century, ed. P. Diamond, 43-52. London: I.B. Tauris.

George, A., and A. Bennett. 2005. Case studies and theory development in the social science. Cambridge: MIT Press.

Gilpin, R. 1981. War and change in international politics. Cambridge: Cambridge University Press.

Goddard, S. 2018. Embedded revisionism: networks, institutions, and challenges to world order. International Organization 72 (4): 763-797.

Gourevitch, P. 1978. The second image reversed. International Organization 1: 881-912.

Grossman, G.M., and E. Helpman. 1994. Protection for Sale. American Economic Review 84 (4): 833-850.

Hays, J.C., S.D. Ehrlich, and C. Peinhardt. 2005. Government spending and public support for trade in the OECD: An empirical test of the embedded liberalism thesis. International Organization 59 (2): 473-494.

Hiscox, M.J. 2001. Class versus industry cleavages: inter-industry factor mobility and the politics of trade. International Organization 55 (1): 1-46.

Huntington, S.P. 1999. The lonely superpower. Foreign Affairs 78 (2): 35-49.

Iancovichina E. and W. Martin. 2004. Impacts of China's accession to the world trade organization. The World Bank Economic Review 18 (1): 3-27.

Jensen, J.B., D.P. Quinn, and S. Weymouth. 2017. Winners and losers in international trade: the effects on U.S. presidential voting. International Organization 71 (3): 423-457.

Katzenstein, P.J. 1985. Small States in World Markets: Industrial Policy in Europe. Ithaca: Cornell University Press.

Kim, I.S. 2017. Political cleavages within Industry: firm-level lobbying for trade liberalization. American Political Science Review 111 (1): 1-20.

Kohout, F. 2003. Cyclical, hegemonic, and pluralistic theories of international relations: some comparative reflections on war causation. International Political Science Review 24 (1): 51-66.

Kriesi, H. 2014. The populist challenge. West European Politics 37 (2): 361-368.

Lake, D. 1993. Leadership, hegemony, and the international economy: Naked emperor or tattered monarch with potential? International Studies Quarterly 37 (4): 459-489. 
Levy, J. 1991. Long cycles, hegemonic transitions, and the long peace. In The Long Postwar Peace, ed. C.W. Kegley, 147-176. New York: HarperCollins.

Levy, J. 2008. Case studies: type, designs and logics of inference'. Conflict Management and Peace Science 25 (1): 1-18.

Mansfield, E., and D. Mutz. 2009. Support for free trade: self-interest, sociotropic politics, and out-group anxiety. International Organization 63 (3): 425-257.

Manyin, M., Daggett, S., Dolven, B., Lawrence, S., Martin, M., O’Rourke, R., \& Vaughn, B. 2012. Pivot to the Pacific? Obama administration rebalancing toward Asia. Congressional Research Service Report for Congress, 28 March, https://fas.org/sgp/crs/natsec/R42448.pdf. Accessed 2 Dec 2020.

Margalit, Y. 2012. Lost in globalization: international economic integration and the sources of popular discontent. International Studies Quarterly 56 (3): 484-500.

Mastanduno, M. 2019. Partner politics: Russia, China, and the challenge of extending US hegemony after the cold war. Security Studies 28 (3): 479-504.

Mayda, A.M. and Rodrik, D. 2005. Why are some people (and Countries) more protectionist than others? European Economic Review, 49(6): 1393-1430.

Mearsheimer, J. 2001. The tragedy of great power politics. New York and London: W.W. Norton \& Company.

Mearsheimer, J. 2019. Bound to fail: the rise and fall of the liberal international order. International Security 43 (4): 7-50.

Milner, H. 1997. Interests, institutions, and information: domestic politics and international relations. Princeton: Princeton University Press.

Milner, H., and B.P. Rosendorff. 1997. Democratic politics and international trade negotiations: elections and divided government as constraints on trade liberalization. Journal of Conflict Resolution 41 (1): $117-147$.

Mudde, C. 2004. The populist zeitgeist. Government and Opposition 39 (4): 542-563.

Musgrave, P. 2019. International hegemony meets domestic politics: why liberals can be pessimists. Security Studies 28 (3): 451-478.

Narlikar, A. 2010. New powers in the club: The challenges of global trade governance. International Affairs 86 (3): 717-728.

National Association of Manufacturers. 2016. Manufacturers endorse Trans-Pacific partnership. Press Release, 4 January, http://documents.nam.org/Nam.org_Web_Archive/www.nam.org/Newsroom/ Press-Releases/2016/01/Manufacturers-Endorse-Trans-Pacific-Partnership/index.html. Accessed 28 July 2021.

National Retail Federation. 2015. NRF praises conclusion of Trans-Pacific partnership agreement. Press Release, 5 October.

National Small Business Association. 2015. NSBA Endorses TPP Deal. Press Release, 9 December, https://nsba.biz/nsba-endorses-tpp-deal-as-good-for-small-business/. Accessed 28 March 2021.

Owen, J.M. 2020. Sino-Russian cooperation against liberal hegemony. International Politics 57 (3): 809-833.

Petri, P. and M. Plummer. 2016. The economic effects of the Trans-Pacific partnerhsip: new estimates. Peterson Institute for International Economics Working Paper No. 16-2, East-West Center Workshop on Mega-Regionalism - New Challenges for Trade and Innovation, https://ssrn.com/abstract= 2723413.

Putnam, R.D. 1988. Diplomacy and domestic politics: the logic of the two-level games. International Organization 42 (3): 427-460.

Rodrik, D., and R. Di Tella. 2020. Labour market shocks and the demand for trade protection: evidence from online surveys. Economic Journal 130: 1008-1030.

Rodrik, D. 2018. Populism and the economics of globalization. Journal of International Business Policy 1 (1): 12-33.

Rodrik, D. 1998. Why do more open economies have bigger governments? Journal of Political Economy 106 (5): 997-1032.

Rosendorff, B.P., and A. Smith. 2018. Domestic political determinants of the onset of WTO disputes. Review of International Organizations 13 (2): 243-272.

Ruggie, J.J. 1982. International regimes, transactions, and change: embedded liberalism in the postwar economic order. International Organization 36 (2): 379-415.

Scheve, K., and M.J. Slaughter. 2004. Economic Insecurity and the globalization of production. American Journal of Political Science 48 (4): 662-674. 
Schott, J., B. Kotschwar, and J. Muir. 2013. Understanding the Trans-Pacific partnership. Washington DC: Peterson Institute for International Economics.

Singer, D.J. 1961. The level-of-analysis problem in international relations. World Politics 14 (1): 77-92.

US Chamber of Commerce. 2016. US chamber statement of support for the Trans-Pacific partnership. Statement by president and CEO Thomas J. Donohue, 6 January, https://www.uschamber.com/pressrelease/us-chamber-statement-support-the-trans-pacific-partnership. Accessed 15 December 2020.

US Government. 2011. Remarks by president Obama to the Australian Parliament. The White House, 17 November, https://obamawhitehouse.archives.gov/the-press-office/2011/11/17/remarks-presidentobama-australian-parliament. Accessed 4 January 2021.

US Government. 2014. 2014 Trade Policy Agenda. Washington DC: USTR.

US Government. 2017. The President's trade policy agenda, https://ustr.gov/sites/default/files/files/repor ts/2017/AnnualReport/Chapter\%20I\%20-\%20The\%20President\%27s\%20Trade\%20Policy\%20Age nda.pdf. Accessed 2 February 2021.

Walter, S. 2021. The backlash against Globalization. Annual Review of Political Science 24: 1-22.

Waltz, K.N. 2009. The United States: Alone in the World. In Imbalance of Power: US Hegemony and International Order, ed.I.W. Zartman, pp. 27-36. Boulder, CO: Lynne Rienner.

Publisher's Note Springer Nature remains neutral with regard to jurisdictional claims in published maps and institutional affiliations. 